\title{
Komposisi Kimia dan Kualitas Fisik Daging Ayam Broiler Dimarinasi dengan Pasta Lengkuas pada Lama Penyimpanan Berbeda
}

\author{
Chemical Composition and Physical Quality of Broiler Chicken Marinated with Galangal Paste at Different \\ Storage Times
}

Nuraini $^{1}$, A. M. Tasse ${ }^{1}$, H. Hafid ${ }^{1}$, \& R. D. S. Toba ${ }^{2}$

${ }^{1}$ Staf Pengajar Fakultas Peternakan Universitas Halu Oleo

${ }^{2}$ Fakultas Peternakan Universitas Halu Oleo

Email koresponden author: andimurlinatasse@gmail.com

\begin{abstract}
The aim of this study is to know the chemical composition and physical qualities breast meat broiler which is marinated in $20 \%$ galangal juice. The method used completely randomized design with stroge period, Treatments $O$ hour (To), 3 hours (T1), 6 hours (T2), and 8 hours (T3) and four replications. Each treatment used breast meat broiler (BMB) 100 grams. Variables included chemical composition (moisture and crude protein \%) and physical quality (cooking loss). The data analysis used analysis of Variance (ANOVA) and Tukey's test The results showed that stroge period 9 hours (T3) has significant $(\mathbf{P}<\mathbf{0 . 0 5})$ effect of cooking loss percentage but does not have significant $(\mathrm{P}<0.05)$ effect of moisture content and crude protein content. The conclusion that storage period longer can increase cooking loss percentage and cannot change Chemical composition breast meat broiler marinated with galangal juice.
\end{abstract}

Keywords: galangal juice, chemical quality, physical quality breast broiler

\section{PENDAHULUAN}

Daging broiler merupakan bahan makanan asal hewani yang digemari oleh seluruh lapisan masyarakat namun daging ayam mudah rusak dan mengalami penurunan kualitas kimia dan fisik sehingga daging broiler menjadi tidak layak konsumsi. Oleh karena itu, pengawetan diperlukan untuk menanggulangi terjadinya penurunan kualitas daging broiler. Tindakan pengawetan dapat memperpanjang daya simpan dan mempertahankan kualitas bahan pangan hewani terutama daging (Hafid 2017; Hafid et al. 2017).

Salah satu metode pengawetan daging adalah marinasi. Marinasi merupakan cara merendam daging di dalam bahan perendam atau marinade yang dilakukan sebelum pengolahan (Hafid 2017). Marinade merupakan cairan berbumbu yang berfungsi sebagai bahan perendam daging, biasanya digunakan untuk memperpanjang masa simpan dan mempertahankan kualitas daging. Salah satu bahan yang dapat digunakan sebagai bahan marinasi sekaligus antibakteri adalah rimpang lengkuas (Kiki et al. 2017).

Rimpang lengkuas selain sebagai bumbu penyedap masakan yang biasa dimanfaatkan oleh ibu rumah tangga, lengkuas juga sebagai bahan alami yang mengandung antioksidan dan antibakteri. Minyak atsiri dalam rimpang lengkuas mengandung flavonoid, fenol, dan eugenol dapat menghambat pertumbuhan bakteri. Penelitian sebelumnya telah dilakukan oleh Parwata dan Dewi (2008), minyak atsiri dalam rimpang lengkuas pada konsentrasi 100 ppm dan 1000 ppm aktif dapat menghambat pertumbuhan bakteri E. Coli. Penggunaan rimpang lengkuas berupa jus lengkuas belum banyak digunakan diharapkan dapat berfungsi sebagai pengawet sehingga dapat memperpanjang masa simpan. Berdasarkan uraian di atas maka penelitian dilakukan tentang bagaimana komposisi kimia dan sifat fisik daging broiler yang dimarinasi dengan jus lengkus pada lama penyimpanan berbeda.

\section{MATERI DAN METODE}

\section{Alat dan Bahan}

Bahan yang digunakan untuk penelitian adalah daging broiler bagian dada, rimpang lengkuas (Alpinia galangal L.) dan aquades. Peralatan yang dimanfaatkan dalam penelitian adalah blender, pisau, talenan, timbangan analitik, loyang sebagai wadah marinasi, oven, gelas ukur, tabung reaksi, labu Erlenmeyer, labu kjedhal, corong, desikator, cawan petri, penangas air, pipet tetes, pipet volumetric, aluminium foil, dan alat tulis.

\section{Prosedur}

\section{Persiapan Penelitian}

Pemilihan Rimpang Lengkuas

Rimpang lengkuas diperoleh dari pasar Mandonga di Kendari. Kriteria pemilihan rimpang lengkuas yaitu agak muda karena rimpang tua mengandung serat kasar tinggi. 


\section{Pembuatan Jus Lengkuas}

Rimpang Lengkuas dibersihkan dengan cara kulit dilepaskan (dikupas), dicuci, dan dipotong-potong kecil lalu ditimbang $20 \mathrm{~g}$. Selanjutnya, potongan kecil rimpang lengkuas dimasukkan ke dalam blender lalu digiling sampai halus sehingga didapatkan jus lengkuas.

\section{Pemilihan Sampel Daging Dada Broiler}

Daging broiler diperoleh dari pasar tradisional di Kota Kendari. Daging dibersihkan dari kulit yang melekat pada daging. Setelah itu, daging ditiriskan dan ditimbang masing-masing $100 \mathrm{~g}$ untuk setiap perlakuan dan ulangan.

\section{Pelaksanaan Penelitian}

\section{Marinasi Daging dalam Jus Lengkuas}

Sampel daging broiler sebelum dimarinasi dalam Jus Lengkuas ditusuk-tusuk menggunakan garpu, lalu dimarinasi dalam jus Lengkuas selama 30 menit.

\section{Peyimpanan Daging Broiler Termarinasi}

Daging Broiler yang termarinasi disimpan pada suhu ruangan selama 0, 3, 6, 9 jam. Setelah itu, dilakukan uji fisik dan kimia pada daging broiler yang telah mengalami penyimpanan.

\section{Rancangan Penelitian}

Penelitian dilakukan dengan menggunakan metode eksperimental dengan lama penyimpanan sebagi perlakuan yaitu $\mathrm{P} 0=0$ jam, $\mathrm{P} 1=3$ jam, $\mathrm{P} 2=6$ jam, dan $\mathrm{P} 4=9$ jam. Rancangan yang digunakan adalah rancangan acak lengkap (RAL) dengan 4 perlakuan dan 4 ulangan.

\section{Kualitas Fisik}

\section{Variabel Penelitian}

\section{Susuk Masak (Cooking Loss)}

Sampel daging broiler termarinasi jus lengkuas dimasak pada suhu $80^{\circ} \mathrm{C}$ selama 60 menit, lalu didinginkan pada suhu ruangan. Setelah itu, sampel daging dibersihkan menggunakan lap kain atau tissue untuk menyerap air pada permukaan daging. Selanjutnya, sampel daging ditimbang untuk mengetahui bobot setelah pemasakan. Persentase susut masak (cooking loss percentage) daging dihitung dengan rumus sebagai berikut :

Susuk masak $(\%)=\underline{\text { berat sebelum dimasak-berat setelah dimasak }} \times 100 \%$ berat sebelum dimasak

\section{Kualitas Kimia}

Kualitas kimia meliputi sifat fisik (kadar air dan kadar protein) mengikuti ADAC (2005).

\section{Analisis Data}

Data dianalisis berdasarkan sidik ragam dan uji beda nyata terkecil (BNT) menggunakan perangkat Lunak SPSS 16.0 .

\section{HASIL DAN PEMBAHASAN}

Sifat fisik daging termarinasi jus lengkuas meliputi persentase susut masak. Sedangkan sifat kimia daging termarinasi jus lengkuas meliputi kadar air dan kadar protein karkas. Rataan nilai sifat fisik dan sifat kimia daging broiler termarinasi jus lengkuas $20 \%$ dengan lama penyimpanan berbeda disajikan pada Tabel 1 .

Tabel 1. Rataan persentase susuk masak, kadar air dan kadar protein kasar pada daging broiler termarinasi jus lengkuas dengan lama penyimpanan berbeda

\begin{tabular}{lccccc}
\hline Parameter & P0 & P1 & P2 & P3 & SEM \\
\hline $\begin{array}{l}\text { Susuk masak } \\
(\%)\end{array}$ & $32,42 \mathrm{~d}$ & $32,84 \mathrm{c}$ & $33,22 \mathrm{~b}$ & $34,31 \mathrm{a}$ & 0,05 \\
Kadar air (\%) & 74,33 & 73,88 & 73,20 & 73,56 & 0,44 \\
$\begin{array}{l}\text { Kadar Protein } \\
(\%)\end{array}$ & 17,75 & 14,62 & 17,62 & 17,54 & 1,14 \\
\hline
\end{tabular}

Keterangan : Angka yang diikuti superkrip berbeda pada baris sama menunjukkan perbedaan nyata $(\mathrm{P}<0,01)$

\section{Komposisi Kimia Daging Dada Broiler Termarinasi Lengkuas}

Komposisi kimia daging yang diukur pada penelitian ini meliputi kadar air dan kadar protein. Rataan kadar air dan kadar protein daging dada broiler termarinasi jus lengkuas $20 \%$ dengan lama simpan yang berbeda dapat dilihat pada Tabel 1.

\section{Kadar Air}

Data pada Tabel 1, perlakuan lama simpan yang berbeda memberikan pengaruh tidak nyata $(\mathrm{P}>0,05)$ terhadap kadar air daging dada broiler termarinasi jus lengkuas 20\%. Artinya lama penyimpanan 0-9 jam pada suhu ruangan tidak mengubah kadar air daging dada broiler termarinasi jus lengkuas.

Kisaran kadar air (\%) daging broiler termarinasi jus lengkuas yang disimpan pada suhu ruangan selama 0-9 jam sekitar 73,30-74,33\%. Kadar air hasil penelitian ini tidak berbeda jauh dengan kadar air daging broiler yang dimarinasi jus daun sirih yang dilaporkan Hamka (2013) yaitu $73,00-73,25 \%$ dan ayam broiler yang diberi pakan limbah undang fermentasi Apergillus Niger pada penelitian Rosyidi et al. (2009) yaitu 74,86\%.

Hasil Penelitian ini menunjukkan kandungan air dalam daging dada broiler termarinasi lengkuas termasuk air terikat sangat kuat secara kimiawi oleh gugus reaktif protein dan air bebas yang berada diantara molekul protein. Hal ini menyebabkan kadar air tidak mengalami perubahan meskipun daging telah mengalami penyimpanan selama 6 jam.

\section{Kadar Protein}

Data pada Tabel 1, perlakuan lama simpan yang berbeda memberikan pengaruh tidak nyata $(\mathrm{P}>0,05)$ terhadap kadar protein daging dada broiler termarinasi jus lengkuas 20\%. Artinya, lama penyimpanan 0-9 jam menghasilkan kadar protein yang tidak berbeda nyata dalam daging dada broiler termarinasi jus lengkuas.

\section{Persentase Susuk Masak Daging Broiler Termarinasin Jus Lengkuas}

Data pada Tabel 1 menunjukkan lama penyimpanan $(0,3,6,9$ jam $)$ memberikan pengaruh yang nyata $(P<0,01)$ 
terhadap persentase susut masak daging broiler termarinasi jus lengkuas 20\%. Lama penyimpanan 0 jam (P0 $=32,42$ \%) menghasilkan susuk masak sangat nyata lebih rendah dibandingkan dengan lama penyimpanan 3 jam $(\mathrm{P} 1=32,84$ $\%), 6$ jam $(\mathrm{P} 2=33,22), 4$ jam $(\mathrm{P} 3=34,31 \%)$. Selanjutnya, lama penyimpanan 3 jam (P1) lebih rendah dibandingkan dengan 6 jam (P2) lebih rendah dibanding dengan 9 jam (P3), artinya lama simpan 9 jam (P3) menghasilkan persentase susut masak tertinggi dan lama simpan 0 jam (P0) menghasilkan persentase susut masak terendah. Hal ini menunjukkan semakin lama penyimpanan, semakin tinggi persentase susut masak pada daging dada broiler termarinasi jus lengkuas 20\%. Hasil penelitian Suradi (2006) yang menggunakan daging broiler tanpa marinasi dengan lama penyimpanan 0-12 jam pada suhu ruangan meningkatkan persentase susut masak dari $32,48 \%$ sampai $34,76 \%$.

\section{KESIMPULAN}

Lama penyimpanan 0-9 jam daging dada broiler termarinasi jus lengkuas 20\% mampu mempertahankan komposisi kimia meliputi kadar air dan kadar protein tetapi meningkatkan persentase susut masak. Semakin lama waktu penyimpanan, semakin tinggi susut masak yang dihasilkan daging dada broiler termarinasi jus lengkuas $20 \%$.

\section{DAFTAR PUSTAKA}

Hafid, H, Mujianto, D. Agustina, Inderawati, \& Nuraini. 2017. The effect of storage time in the refrigerator to the quality of organoleptic beef. ADRI International Journal of Biology Education. 1(1): 29-36.

Hafid, H. 2017. Pengantar Pengolahan Daging. Cetakan Pertama. Penerbit Alfabeta. Bandung.

Hamka, M. 2013. Pengaruh pemberian jus daun sirih terhadap persentase susut masak dan komposisi kimia daging dada ayam broiler. Skripsi. Jurusan Peternakan Universitas Halu Oleo. Kendari

Kiki, R., Hasana, H. Hafid, \& L. Malesi. 2017. Nilai nutrisi daging sapi setelah perendaman dalam jus rimpang laos (Alpina galanga). Jurnal Ilmu dan Teknologi Peternakan Tropis. 4(1):13-20.

Parwata, I. M., P. F. S. Dewi. 2008. Isolasi dan uji aktivitas antibakteri minyak atsiri dari rimpang lengkuas (Alpina galangga L.). Jurnal Kimia. 2(2):100-104.

Rosyidi, D., A. Susilo, \& R. Muhbianto. 2009. Pengaruh penambahan limbah undang fermentasi Apergillus Niger pada pakan terhadap kualitas fisik daging ayam broiler. Jurnal Ilmu dan Teknologi Hasil Ternak, 4(1):110.

Zulkarnain, D. 2008. Pengaruh suplementasi tepung kunyit (Curcuma domestica Valet) sebagai bahan antioksidan dalam ransum terhadap performa dan kualitas karkas ayam broiler. Tesis. Universitas Gajah Mada. Yogyakarta. 